\title{
BELARUSIAN-POLISH TRANS-BOUNDARY REGIONAL COOPERATION: FACTORS AND PROBLEMS OF DEVELOPMENT
}

\author{
SERGEJ ARTEMENKO \\ Faculty of Geography, Belarusian State University \\ Leningradskaja St., 16, 220030 Minsk, Belarus \\ e-mail: serg2462@mail.ru
}

\begin{abstract}
This paper presents features Belarusian-Polish trans-boundary regional cooperation. The factors and conditions of such cooperation are characterized. The problems in interaction between two countries which have arisen after the introduction of Poland in Shengen zone are marked.

Key words: trans-boundary regional cooperation, regional relations, euroregion, border transport infrastructure
\end{abstract}

\section{INTRODUCTION}

Regionalization, as well as globalization, is one of the two main tendencies of the modern world development. They embrace all the countries of the world, though the forms of their government differ depending on the level of economic development of the particular states. The processes of globalization and regionalization actually become, "first, inter-connected, second, politically motivated" (Entering the 21st century... 1999).

At the end of the 20th-beginning of the 21st centuries there intensified the tendency to create both new forms and to increase the number of the integration groupings which resulted in the appearing of the term "new regionalism". The main attribute of the new regionalism is expanded size and openness to another countries. New regionalism does not strive for autarchy but concentrates and unites political and economic might of the countries that want to increase their competitive abilities in the global economy. 
Modern regions include two levels of cooperation: international and interregional, besides, regional integration is best achieved particularly at the subregional level. It happens only when these subregions are actually the actors of the international economic cooperation (i.e. have the possibility to make trans-boundary contacts independently from their states). At that, the region relies on one or the other competitive advantages.

After the end of the "cold war" there were formed the suppositions for the appearance of the absolutely new type of the community-trans-boundary region, which can at the same time include both states and the separate parts of the states as the actors, that underlines the heterogeneity of the trans-boundary region in the way of the constitutive parts. Construction of the international region is the main source of the economic interdependence in the region. For this purpose one needs regional institutes of the economic governing, besides, survival of the region, the level of its economic integration are fully dependable on the degree of the stability of these institutions. The presence of the trans-boundary region, as well as its frontiers are determined by the character of the programs of the economic interaction and the actual economic practice.

\section{TRANS-BOUNDARY INTERACTION}

They have a special meaning in Europe where the processes of border interaction and integration are intense. Western Europe has quite rich experience of activation of the social-economic development of the peripheral regions of the states on the basis of their trans-boundary cooperation. Border regions of the states of this part of Europe try to unite their efforts in different spheres and together appear on the international arena to declare their own position in European matters. At present, the main element in the system of such cooperation is the organization of the border territories' connections in the form of the euroregions-special zones of the trans-boundary cooperation.

Euroregions are formed as the means of providing and strategic planning of the cooperation that solves the following problems:

- gradual harmonization of the legal, economic and governing systems, contributing to the free development of the border regions;

- creating favourable conditions for close contacts between small and middle-sized enterprises situating on the both sides of the border;

- providing the process of the development of the information systems standardization for the purposes of information exchange simplification;

- mutual work in the sphere of tourism and development of nature protection activities; - cooperation in the sphere of communications and transport.

The experience of many European countries show that the participation of their border regions in euroregional cooperation allows to solve their problems more 
efficiently at the level of the municipalities of the bordering administrative-territorial units. Flexible economic structures (join-stock companies, consortiums and etc.) with the involving of the international investments for building or enlarging transboundary transport-communication infrastructure are formed. Border trade and tourism are improved. The problems of illegal immigration and trans-boundary crime, the problems connected to the trans-boundary migrations of the labour force are solved mutually. The cooperation in the spheres of education, culture and ecology is widened.

So, euroregions in Europe are viewed as the stimulus of the political, economic and cultural cooperation at the local level for the solution of the wide circle of problems of the border territories.

Complex system of the regional relations is formed under the influence of group of factors of different nature. The factors of the precondition character are geogra phical, cultural, social-psychological, etc. The factors constituting the basis, the core of the regional contacts are economic. The third group is political, the factors that have the character of subjective will-power under any configuration of the regional construction (Muntyan 1996, p. 125).

Important preconditions of the appearance and development of the trans-boundary interaction are border situation, common historical past, ethnic and cultural closeness, social-economic connections and their perspectives, common (similar) problems of the regional development, including ecological, the presence of the needed infrastructure of the interaction (border and customs, transport and communications), political will and the corresponding legal base.

In the integrating Europe the special conditions for the development of the transboundary contacts appeared in its eastern and south-eastern parts in the range of the post-social and post-soviet space. The countries of the transitional type that include Belarus and Poland, countries-neighbours, are reformed and developed in their own way with the different degree of success and different geopolitical marks. Though, territorial closeness, historical-cultural conditions of the development of the two countries in the past and good neighbouring and mutually profitable relations at present orient these countries for the search of the ways for closer interaction and cooperation for the benefit of their peoples.

\section{POLISH-BELARUSIAN INTERACTIONS}

At present, the cooperation of Belarus and Poland is developing quite effectively and progressively. The agreements in such areas as economy, culture, social sphere are signed and put in action. The work on the development, enlargement and increasing of the effects of the cooperation, the search of its new itineraries and forms is being conducted. Among such forms at present special place is given to the regional transboundary cooperation. 
Interaction of the two countries in the network of euroregions can be considered the attempt and the result of the imitation of effectively developing functional territorial forms of the trans-boundary cooperation in Europe. Not being an EU member, Belarus, nevertheless, tries to apply the statements of the European framework convention about the border cooperation of the territorial communities and the governments that was accepted on May 21st, 1980 in Madrid, and which determines rather voluntary than legally agreed cooperation limits. The regions of Belarus and Poland are the members of three euroregions-"Bug" (1995), "Neman" (1997), "Beloveshchskaya pustcha" (2002).

The experience of Belarus participating in the euroregional cooperation allows us to talk about the mechanism of the euroregions being very important not only for the solution of the actual territorial problems but also for much wider tasks. Besides, they are not exclusively Belarusian. The success of the fight with the illegal migration, drug trafficking, human traffic, organized crime depends on the facilities of the customs checkpoints, close cooperation of the border, police and administrative authorities. That is why EU pays so much attention to this question.

In the network of euroregions with the participation of Belarus the attempts to solve a wide range of regional and local problems at the first place are made in the way of mutual programs realization. Territorial structures of the economy and settling of the two countries are adopted for the potential interaction, for instance, within the immediate closeness to the frontier the economic structures with special regime-FEZ "Brest" (Belarus), "Malaszewicze" (Poland) are formed and in function; in both countries some state programs, the purpose of which is the support of the socialeconomic development of small towns (including those in the border zone), etc. were worked out and are in effect.

At present the most successful is the cooperation between the two countries in such spheres as tourism and border transport infrastructure.

On the 27th of December, 1995 the agreement "On the cooperation in the field of tourism" was signed between the Republic of Belarus and the Republic of Poland. Among the most significant mutual tourist projects one should mention, for instance, the reconstruction of the August canal, which in perspective can become an element of the small water ring of Eastern Europe and with the reconstruction of the Oginsky canal there appears a possibility to close the Baltic and the Black Sea water systems.

Significant changes are taking place in the development of the border transport infrastructure. 12 border checkpoints with different types of control were opened and are working at the Belarus-Polish border (Table 1).

Lately with EU financial support the reconstruction of the border checkpoints (BCP) at the Belarus-Polish frontier has been done-"Warsaw bridge", "Kozlovitchy-2" (on November 20th, the construction of the first starting complex of the first stage of this border cargo terminal (BCT) was completed). The construction of the terminal within the immediate closeness to the state frontier is directly linked to the functioning of the international automotive checkpoint Kozlovotchy-Kukuryki 
Table 1. Control checkpoints at Belarusian-Polish border

\begin{tabular}{|c|c|c|c|}
\hline Border checkpoint & Type of the checkpoint & Location & Control types ${ }^{1}$ \\
\hline $\begin{array}{l}\text { Brest } \\
\text { (Terespol) }\end{array}$ & $\begin{array}{l}\text { Border checkpoint at } \\
\text { the railway station }\end{array}$ & $\begin{array}{l}\text { Brest, station Brest- } \\
\text {-Vostochny in the cen- } \\
\text { tral district, station } \\
\text { Brest-Vostochny in } \\
\text { the western district, } \\
\text { station Brest-Severny, } \\
\text { park Zarechytsa }\end{array}$ & $\begin{array}{l}\text { Sanitary-quarantine, } \\
\text { veterinary, phytosa- } \\
\text { nitary }\end{array}$ \\
\hline $\begin{array}{l}\text { Grodno } \\
\text { (Kuznica Bialostocka) }\end{array}$ & $\begin{array}{l}\text { Checkpoint at the rail- } \\
\text { way station }\end{array}$ & $\begin{array}{l}\text { Grodno, station Grod- } \\
\text { no, Grodno region, } \\
\text { station Bruzgy }\end{array}$ & $\begin{array}{l}\text { Sanitary-quarantine, } \\
\text { veterinary, phytosa- } \\
\text { nitary }\end{array}$ \\
\hline $\begin{array}{l}\text { Vysokolitovsk } \\
\text { (Czeremcha) }\end{array}$ & $\begin{array}{l}\text { Checkpoint at the rail- } \\
\text { way station }\end{array}$ & $\begin{array}{l}\text { Brest region, Kame- } \\
\text { nets district, station } \\
\text { Vysokolitovsk }\end{array}$ & $\begin{array}{l}\text { Sanitary-quarantine, } \\
\text { veterinary, phytosa- } \\
\text { nitary }\end{array}$ \\
\hline $\begin{array}{l}\text { Svisloch } \\
\text { (Siemianowka) }\end{array}$ & $\begin{array}{l}\text { Checkpoint at the rail- } \\
\text { way station }\end{array}$ & $\begin{array}{l}\text { Grodno region, Svis- } \\
\text { loch district, station } \\
\text { Svisloch }\end{array}$ & $\begin{array}{l}\text { Sanitary-quarantine, } \\
\text { veterinary, phytosa- } \\
\text { nitary }\end{array}$ \\
\hline $\begin{array}{l}\text { Berestovitsa } \\
\text { (Bobrowniki) }\end{array}$ & $\begin{array}{l}\text { Automotive check- } \\
\text { point }\end{array}$ & $\begin{array}{l}\text { Grodno region, Bere- } \\
\text { stovitsa district, } \\
\text { Pogranichny }\end{array}$ & $\begin{array}{l}\text { Sanitary-quarantine, } \\
\text { veterinary, phytosa- } \\
\text { nitary, automotive }\end{array}$ \\
\hline $\begin{array}{l}\text { Brest } \\
\text { (Terespol) }\end{array}$ & $\begin{array}{l}\text { Automotive check- } \\
\text { point }\end{array}$ & $\begin{array}{l}\text { Brest, Warsaw High- } \\
\text { way, M1 }\end{array}$ & $\begin{array}{l}\text { Sanitary-quarantine, } \\
\text { veterinary, phytosa- } \\
\text { nitary, automotive }\end{array}$ \\
\hline $\begin{array}{l}\text { Bruzgy } \\
\text { (Kuznica Bialostocka) }\end{array}$ & $\begin{array}{l}\text { Automotive check- } \\
\text { point }\end{array}$ & $\begin{array}{l}\text { Grodno region, Grod- } \\
\text { no district, village } \\
\text { Bruzgy }\end{array}$ & $\begin{array}{l}\text { Sanitary-quarantine, } \\
\text { veterinary, phytosa- } \\
\text { nitary, automotive }\end{array}$ \\
\hline $\begin{array}{l}\text { Domachevo } \\
\text { (Slawatycze) }\end{array}$ & $\begin{array}{l}\text { Automotive check- } \\
\text { pointt }\end{array}$ & $\begin{array}{l}\text { Brest region, Brest } \\
\text { district, t.s. Doma- } \\
\text { chevo }\end{array}$ & $\begin{array}{l}\text { Sanitary-quarantine, } \\
\text { veterinary, phytosa- } \\
\text { nitary, automotive }\end{array}$ \\
\hline $\begin{array}{l}\text { Kozlovichy } \\
\text { (Kukuryki) }\end{array}$ & $\begin{array}{l}\text { Automotive check- } \\
\text { point }\end{array}$ & Brest & $\begin{array}{l}\text { Sanitary-quarantine, } \\
\text { veterinary, phytosa- } \\
\text { nitary, automotive }\end{array}$ \\
\hline $\begin{array}{l}\text { Pestchatka } \\
\text { (Polowce) }\end{array}$ & $\begin{array}{l}\text { Automotive check- } \\
\text { point }\end{array}$ & $\begin{array}{l}\text { Brest region, } \\
\text { Kamenets district, } \\
\text { village Pestchatka }\end{array}$ & $\begin{array}{l}\text { Sanitary-quarantine, } \\
\text { veterinary, phytosa- } \\
\text { nitary, automotive }\end{array}$ \\
\hline $\begin{array}{l}\text { Lesnaya } \\
\text { (Rudawka) }\end{array}$ & $\begin{array}{l}\text { Checkpoint of simpli- } \\
\text { fied passing }\end{array}$ & $\begin{array}{l}\text { Grodno region, Grod- } \\
\text { no district, village Les- } \\
\text { naya }\end{array}$ & \\
\hline $\begin{array}{l}\text { Pererov } \\
\text { (Bialowieza) }\end{array}$ & $\begin{array}{l}\text { Checkpoint of simpli- } \\
\text { fied passing }\end{array}$ & $\begin{array}{l}\text { Brest region, Prush- } \\
\text { chany district, village } \\
\text { Pererov }\end{array}$ & \\
\hline
\end{tabular}

1 except border and customs 
It was created in 1984 and since then it was widened and modernized a lot. At first, its infrastructure represented a building and the facilitated ground for 180 trucks. By the end of the 20th century "Kozlovichy" had become the biggest customs clearance point in the western direction, it had got actual international acknowledgement and had been included in the reference books and data bases of all major expeditions of Europe. As a result of the reconstruction the passing capacity of the terminal "Kozlovitchy" will reach 4 thousand trucks that will correspond to the capacity of the border terminal in Koroshchin (RP). The existing parking ("buffer station") for 270 automobiles and the grounds for 85 auto-trains will contribute to it as well as extra working places for all the representatives of services functioning at the border.

The modernization of the checkpoints "Bruzgy", "Berestovitsa" and "Domatchevo" has started. Besides, in 2009 the project of reconstruction of the automotive checkpoint "Pestchatka" was worked out and its construction is planned for 2010-2012. The participation of EU in the development of border infrastructure in the Republic of Belarus became possible due to the Program of border cooperation.

At present the system of border control is significantly modernized. Thus, since January 1, 2008 the single automated system of border control (ASBC) began its work at the Belarusian checkpoints. It allowed to decrease the time of border clearance tenfold by eliminating such human factors as tiredness or poor attention. New equipment allows to control the situation at the real time at all the checkpoints, to assess the documents' authenticity, to read off the passport data and to check it against the data bank.

The introduction of this system removed the necessity of putting the stamp permitting visits abroad and date-stamps while crossing the border in the passports. At present ASBC is an important element of the modern system of managing the state border of Belarus.

The mobile laboratory of operational reaction (MLOR) was employed to work with the cargoes. The automated system "ASUPKAP" has been tested and will be employed at every checkpoint. It allows to unite the data of various types of control at the border-transport, phytosanitary, border, customs, etc. in the single system.

The mechanism of the customs clearance is being mastered in Belarus. Customs committee of the Republic of Belarus continues active application of the national automated system of electronic declaration that shortens the time of customs papers execution by 6 times and saves money: one does not need to bring the goods to the customs storehouses, smaller number of people is involved. Another advantage is the elimination of corruption issue as there is no contact between a customs inspector and a representative of the economy subject.

Since September $200967 \%$ of export has been converted to the electronic declaration. This innovation was mastered by more than 800 enterprises-exporters. At present every day up to 1000 electronic customs papers are executed and since June 2009 registration of the electronic statistic declarations has been started. In 2010 they plan to introduce electronic declaration both while clearing passports 
and in the regime of the temporary import and export of the goods. In the nearest future the customs is planning to arrange the exchange of the initial electronic information about the goods and means of transport passing through the border of Belarus and the borders of EU Member States.

In the network of Belarus-Polish cooperation in 1994-2000 a range of work was conducted, the program and conception of the planning organization of border regions of Belarus and Poland were worked out.

At the same time important and to a large degree, determining condition of the development of Belarus-Polish regional trans-boundary cooperation is the solution of the problems of border crossing, developing of trans-boundary transport communications (it, naturally, must be viewed alongside with the development of communication of connections), forming trans-boundary passenger and cargo traffic, their spacious organization (for instance, in the form of international transport corridors).

During the last decade of the 20th century and the first decade of the 21 st century passenger and cargo transportation through Belarus-Polish border has changed their characteristics - directions, size, structure, transport priorities-numerous times. Since the beginning of 90 -s of the 20th century the character of trans-boundary contacts between the two countries has been totally changed. It was connected to the liberalization of border and customs regimes that had led to the relative "openness" of the frontier. The modernization of border infrastructure has begun and to some extend it was created anew. New checkpoints were built and opened, transport network was reconstructed and extended, transport terminals were introduced in function. The barrier frontiers became much weaker. As a result, passenger and cargo traffic through Belarus-Polish border had increased and their size and structure changed many times. The reasons for such changes were political and economic decisions of the state authorities, problems (such as crises, for instance) and the changing tendencies of the country, regional and global economical development, changing of the geopolitical situation, deepening gap in the cost of living and the forming of new features of the mentality of the people of Belarus and Poland, etc. The important aspects of forming and carrying out the trans-boundary movements at that period became (and they preserve its meaning until now) border ("market") trade, new economic ties at the level of small and middle-sized business (enterprise) and intergovernmental economic and cultural cooperation, the formation of which determined the intensity, the conditions of creation and even the geography of border infrastructure.

In the context of the problem connected to the crossing the border between the countries one should pay attention to the important political and at the same time economic facts that to a great extend determine the condition of the movements through Belarus-Polish border. It is entry of Poland into European Union (2004) and in the Shengen zone (2007). 


\section{CONCLUSIONS}

The importance of these events in the relation of the influence on the passenger and cargo traffic through the border is not the same. Polish entry in EU determined formally that the border of the integrated European Union passed at the frontier with the Republic of Belarus and Polish state became the representative of its interest through the direct trans-boundary interaction. As a result, new conditions and forms of interaction including the most important ones for the development of border communities began to form at the frontiers of the two states. The principles and ways of EU in the execution of regional politics of trans-boundary cooperation started to be applied in an imitational way while forming such cooperation between Belarus and Poland. Not all the positive effects of such activity can be seen (for instance, it is difficult to consider successful euroregional cooperation of the two countries), though liberal-democratic approaches and principles of the corporative discipline of European Union in this field have significantly influenced the character of the transboundary interaction.

Polish introduction of visa regime has, to some extend, complicated the direct interaction of the two countries at the macroeconomic level (for instance, goods transportation, services) and significantly influenced the number of movements through the border with various aims (trade, shopping, tourism) of people. The result is the decrease of the passenger traffic to the level of Soviet time. At the same time we can suppose, that the decrease of the general passenger traffic, happened particularly, because of the decrease of the number of movement of people of Belarus through the border (the number of Polish people has been insignificant before the introduction of the visa regime (since 1991) and after this event-maximum 2,1-2,2 million people),their share in the movements through Belarus-Polish border is about $60 \%$ (at the insignificant share of transit passengers-about $10 \%$ ).

Low trans-boundary mobility of the Poles is determined, more likely, by the positive changes of the macroeconomic situation in the country, growth of the life level and as a result, considerable decrease of the economic interest in the border trade at the territory of the neighbouring state.

The transportation of goods through Belarus-Polish border is defined, in general, by the intergovernmental interactions and it was regulated by the system of mechanisms of external economic activity execution. Probably, these trans-boundary movements to much smaller degree were determined by the political and microeconomic factors. The growth of goods movements that lasted until the year 2003 was connected to the economic reviving in both countries, other post-soviet states (transit cargo transportation), based on the reformation of economy, retargeting and intensification of the external economic ties.

At the same time, taking into consideration the interaction of the two states in this movement, one should mark that unlike the passenger traffic, the participation in the cargo transportation of Belarusian economy subjects in their general size of 
economy is not significant. It is connected to the general economic particularities of the country development.

According to the statistics of the Soviet of ministers of the Republic of Belarus the volume of the external trade of goods in Belarus in January-September 2009 comprised 35,1 milliard US dollars that is $38.7 \%$ less than in January-September 2008. The balance of the external trade was negative at the size of 4,9 milliard US dollars (in January-September 2008 negative at the size of 3,9 milliard US dollars). Export of the Republic of Belarus comprised 15,1 milliard US dollars and decreased in comparison with the corresponding period of the year 2008 by $43.4 \%$. Import of the Republic of Belarus in the present year decreased by $34.7 \%$ and comprised 20 milliard US dollars (External trade of 2008).

Commodity circulation with EU countries in comparison with January-September 2008 decreased by $37 \%$ and comprised 11,1 milliard US dollars (31.7\% of the general commodity circulation of the Republic of Belarus). Export decreased by $43.5 \%$ and comprised 6,5 milliard US dollars, import decreased by $24.8 \%$ and comprised 4,6 milliard US dollars.

Though the main trading partners of Belarus among the non CIS states are the Netherlands, Germany, Poland, Great Britain, Italy, commodity circulation with these countries significantly decreased: with the Netherlands by 1,8 million US dollars, Poland - by 1,2 milliard US dollars, Great Britain-by 629 million US dollars, Germany—by 446,2 million US dollars (Belarus in 2009).

The given tendencies of the external economic activity find their reflection in the character of the trans-boundary movement of cargos.

At the background of the decrease of external economic activity of Belarusian economy subjects the accents of the cargo transportation will be likely moved in the direction of the transit goods. Entrance of the Republic of Belarus in the Customs union with the Russian Federation and Kazakhstan (from January 1, 2009) will require further perfection of border transport infrastructure of international importance-border checkpoints, roads, terminals, etc. At the same time, it's necessary to create new elements of such infrastructure and modernize already existing ones in the directions of border cooperation of Belarusian and Polish sides. It will help to intensify and diversify the ties of border communities, to liven up the activity in the existing euroregional structures.

\section{REFERENCES}

Entering the 21st century. World Development Report 1999/2000 (1999), The International Bank for Reconstruction and Development, The World Bank, Oxford University Press, Oxford, 1-11.

Muntyan, M. A. (1996), Internationalization, integration and regionalization of the world (problem stating), Problems of global and regional processes, 123, Moscow. 
External trade of goods in the Republic of Belarus for 2008. Information by MIA RB $<$ http://www.mfa.gov.by/ru/economic/foreign-trade/jm2008/> (02.12.2009).

Belarus in January-September 2009 traded with 176 countries <http://www.government.by/ru/rus_analytics1800.html > (02.12.2009). 